Article

\title{
Novel Cationic Meso-Arylporphyrins and Their Antiviral Activity against HSV-1
}

\author{
Kseniya A. Zhdanova ${ }^{1, *}$, Inga O. Savelyeva ${ }^{1}$, Artem V. Ezhov ${ }^{1}$, Andrey P. Zhdanov ${ }^{2}{ }^{\oplus}$, Konstantin Yu. Zhizhin ${ }^{1,2}$, \\ Andrey F. Mironov ${ }^{1}$, Natal'ya A. Bragina ${ }^{1}$, Alla A. Babayants ${ }^{3}$, Irina S. Frolova ${ }^{3}$, Nadezhda I. Filippova ${ }^{3}$, \\ Nadezhda N. Scliankina ${ }^{3}$ and Olga N. Scheglovitova ${ }^{3}$ \\ 1 MIREA-Russian Technological University, Vernadsky Prospect 86, Moscow 119571, Russia; \\ inga.saveleva.96@mail.ru (I.O.S.); arx1mond@ya.ru (A.V.E.); zhizhin@igic.ras.ru (K.Y.Z.); \\ mironov@mitht.ru (A.F.M.); n.bragina@mail.ru (N.A.B.) \\ 2 Kurnakov Institute of General and Inorganic Chemistry of the Russian Academy of Sciences, Leninskii Pr. 31, \\ Moscow 117907, Russia; zhdanov@igic.ras.ru \\ 3 Gamaleya Research Center of Epidemiology and Microbiology, Gamaleya Str. 18, Moscow 123098, Russia; \\ babayants@gamaleya.org (A.A.B.); frolova@gamaleya.org (I.S.F.); gecnst105@gmail.com (N.I.F.); \\ nvsklankina@yandex.ru (N.N.S.); scheglovitova@yandex.ru (O.N.S.) \\ * Correspondence: zhdanova_k@mirea.ru; Tel.: +79-261-126-692
}

\section{check for} updates

Citation: Zhdanova, K.A.; Savelyeva I.O.; Ezhov, A.V.; Zhdanov, A.P.; Zhizhin, K.Y..; Mironov, A.F.; Bragina, N.A.; Babayants, A.A.; Frolova, I.S.; Filippova, N.I.; et al. Novel Cationic Meso-Arylporphyrins and Their Antiviral Activity against HSV-1. Pharmaceuticals 2021, 14, 242. https://doi.org/10.3390/ph14030242

Academic Editor: Maria Emília de Sousa

Received: 7 February 2021

Accepted: 3 March 2021

Published: 8 March 2021

Publisher's Note: MDPI stays neutral with regard to jurisdictional claims in published maps and institutional affiliations.

Copyright: (c) 2021 by the authors. Licensee MDPI, Basel, Switzerland. This article is an open access article distributed under the terms and conditions of the Creative Commons Attribution (CC BY) license (https:/ / creativecommons.org/licenses/by/ $4.0 /)$.
Abstract: This work is devoted to the search for new antiherpes simplex virus type 1 (HSV-1) drugs among synthetic tetrapyrroles and to an investigation of their antiviral properties under nonphotodynamic conditions. In this study, novel amphiphilic 5,10,15,20-tetrakis(4-(3-pyridyl- $n$-propanoyl)oxyphenyl) porphyrin tetrabromide (3a), 5,10,15,20-tetrakis(4-(6-pyridyl- $n$-hexanoyl)oxyphenyl)porphyrin tetrabromide (3b) and known 5,10,15,20-tetrakis(1-methyl-4-pyridinio)porphyrin tetraiodide (TMePyP) were synthesized, and their dark antiviral activity in vitro against HSV-1 was studied. The influence of porphyrin's nanosized delivery vehicles based on Pluronic F127 on anti-HSV-1 activity was estimated. All the received compounds $\mathbf{3 a}, \mathbf{3 b}$ and TMePyP showed virucidal efficiency and had an effect on viral replication stages. The new compound $\mathbf{3 b}$ showed the highest antiviral activity, close to $100 \%$, with the lowest concentration, while the maximum TMePyP activity was observed with a high concentration; porphyrin 3a was the least active. The inclusion of the synthesized compounds in Pluronic F-127 polymeric micelles had a noticeable effect on antiviral activity only at higher porphyrin concentrations. Action of the received compounds differs by influence on the early or later reproduction stages. While $3 \mathbf{a}$ and TMePyP acted on all stages of the viral replication cycle, porphyrin $3 \mathbf{b}$ inhibited viral replication during the early stages of infection. The resulting compounds are promising for the development of utilitarian antiviral agents and, possibly, medical antiviral drugs.

Keywords: viruses; antiviral activity; synthesis; cationic porphyrins; anti-HSV-1; dark antiviral activity of porphyrins; Pluronic F127; nanovehicles

\section{Introduction}

Currently, viruses are becoming a global threat to all of humanity. Herpes viruses are widespread in the human population, and the infectious process they cause is characterized by a chronic latent course, with periods of virus reactivation and the manifestation of the disease [1-3]. A virus causes an acute disease of the mucous membranes of the oral cavity, cornea, gastrointestinal tract, urogenital tract and skin; in rare cases, it causes encephalitis and leads to severe neonatal infection [4,5]. Primary infection always leads to a lifelong virus persistence. A virus reaches the nerve ganglia from the primary focus along the nerve endings, and, in the neurons, the virus goes into latency-associated transcripts (LATs), which are accompanied by the development of latent infection, which can be reactivated [6]. Reactivation of the infection leads to relapse, and, in older people, the local inflammatory process, with viral latency in the neurons, can lead to the development 
of neurodegenerative diseases [7]. Herpetic infection also causes severe complications in immunocompromised patients, pregnant women and newborns [8,9]. According to the cryoelectron tomography, HSV-1 is an enveloped virus, with a sphere diameter of $186 \mathrm{~nm}$ and, including glycoprotein protrusions, a diameter of $225 \mathrm{~nm}$ [10]. Searches for antiherpetic agents to treat and prevent the diseases caused by HSV-1 have been carried out for many years [11]. However, the problem of finding new anti-HSV-1 agents and treatment methods continues to be relevant due to the development of resistance to existing drugs and the lack of a long-term effect from the use of specific prophylactic agents [12].

At present, modified nucleosides or their prodrugs are the most commonly used antiherpetic drug. The mechanism of their action is related to DNA polymerase suppression. The most famous drug is acyclovir (ACV) (Figure 1a), proposed in 1977 [13]. ACV is an effective and nontoxic drug, but it has low oral bioavailability and solubility, as well as a short lifetime in the bloodstream. A series of drugs with higher pharmacological properties has been received, for example, valacyclovir (L-valine ether of ACV, Figure $1 b$ ), ganciclovir (9-(1,3-dihydroxy-2-propoxymethyl)guanine, Figure 1c), etc. Non-nucleoside drugs include derivatives of 1,2,4-triazole[1.5- $\alpha$ ]pyrimidine [14], hydroxyurea [15], foscarnet (Figure 1f), etc. It should also be noted that existing drugs do not relieve patients from the persistent nature of the disease, and the result of their long-term use may give rise to the emergence of resistant strains of the virus, which makes the course of the disease uncontrollable. In this regard, it is important to expand the list of possible antiherpetic drugs among biologically active compounds of various classes and to establish targets for their action.

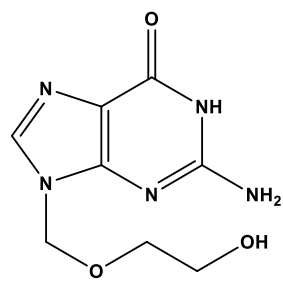

(a)

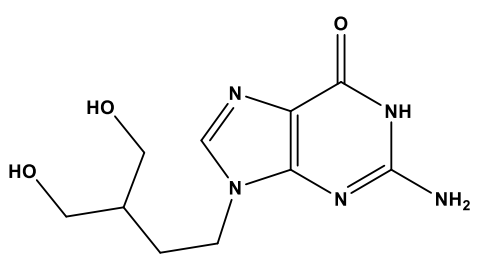

(d)<smiles>CC(C)[C@H](N)C(=O)OCCOCn1cnc2c(=O)[nH]c(N)nc21</smiles><smiles>CC(=O)OCC(CCn1cnc2c(=O)[nH]c(N)nc21)COC(C)=O</smiles>

(e)

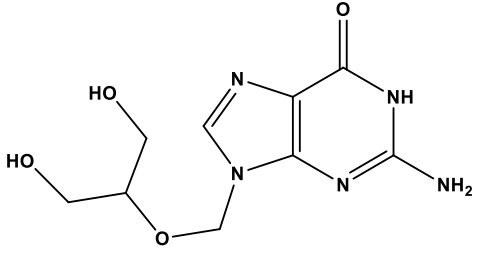

(c)

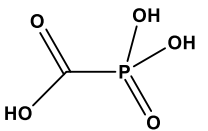

(f)

Figure 1. Antiherpetic drugs used in the clinic: (a) acyclovir, (b) valacyclovir, (c) ganciclovir, (d) penciclovir, (e) famciclovir, (f) foscarnet.

Porphyrins are a unique class of heterocyclic tetrapyrrolic molecule. They play an essential role in vital biological processes of energy conversion and oxygen transfer. Interest in this class of compound is associated with a wide range of applications in various fields of medicine and technology, due to their unique photophysical properties (intense absorption in the visible and near-infrared regions, fluorescence properties, efficient generation of singlet oxygen, etc.) and their chemical and thermal stability [16-24]. Natural porphyrins and their synthetic analogues are widely used as photosensitizers for the photodynamic therapy (PDT) of neoplasms [25-29] and the photodynamic inactivation (PDI) of microorganisms, such as viruses [30-34], bacteria [35-38] and fungi [39,40].

Synthetic porphyrins with positive-charged groups have shown antiviral and antibacterial effects directly depending on their structure [31,33,35]. The cationic charge of the molecule promotes the electrostatic binding of porphyrin to the outer surface of the bacterial cell. DNA is also one of the most specific biological targets for cationic por- 
phyrins. The formation of strong complexes of these compounds with nucleic acids has been reported, including for the recognition of noncanonical structures of DNA called G-quadruplexes [41]. Other authors [42] have shown that the HSV-1 genome contains multiple clusters of repeated G-quadruplex. In this regard, G-quadruplex binding ligands, such as porphyrins, could be envisaged as new therapeutic antiherpetic drugs. Porphyrins with pyridinium residues are especially interesting in this regard. The use of cationic 5,10,15,20-tetrakis (4-methylpyridine-4-yl)porphyrin (TMePyP) and its derivatives against HIV [33,43], bacteriophage MS2 [44], T7 [45] and hepatitis A virus [46] is also known. Elsewhere [31,32], the photoinduced activity of TMePyP derivatives against HSV-1 and HSV-2 have also been shown. The photodynamic virucidal activity of tetrapyrroles against HSV-1 is associated with phototoxic damage of the viral envelope proteins and unsaturated lipids and intracapsid components (nucleic acids and enzymes) [30]. However, a serious drawback of the photodynamic effect is its nonselectivity of cellular structures and the critically damaging action on cells due to reactive oxygen species (ROS). The literature describes few works dealing with the nonphotodynamic effect of tetrapyrroles on HSV-1 [30-32].

In the current work, new amphiphilic cationic meso-arylporphyrins containing pyridinium residues at the periphery of the macrocycle were synthesized (Figure 2), and their antiviral effect against HSV-1 was investigated under nonphotodynamic conditions. The virucidal effect and the effect on HSV-1 Vero infected cells were evaluated. TMePyP was used as a reference compound, because of its widespread use in biological studies of tetrapyrrole compounds.

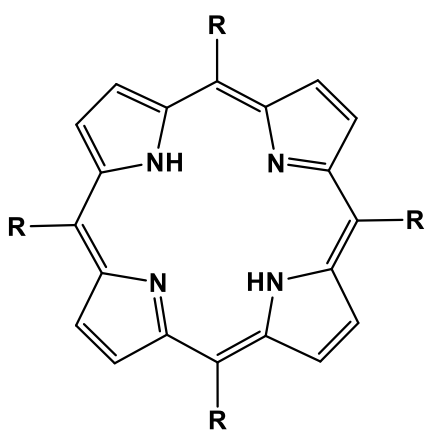

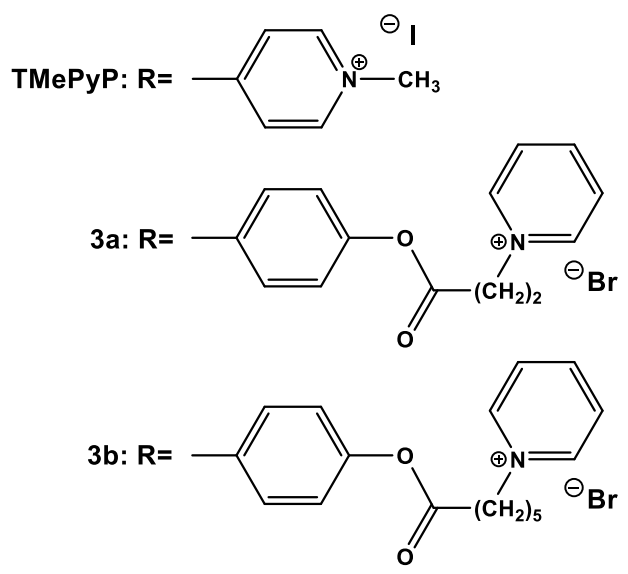

Figure 2. The structures of the investigated compounds.

The hydrophobic nature of the tetrapyrrole macrocycle limits the use of these compounds in biomedicine. An effective approach to overcome this problem is the use of molecular delivery vehicles, such as liposomes, inorganic nanoparticles and polymers $[22,25,27,47]$. In recent years, researchers have shown increased interest in polymer micelles based on Pluronics-amphiphilic triple block copolymers of polyethylene oxide (PEO) and polypropylene oxide (PPO), several of which, including Pluronic F-127, have been approved for clinical use by the FDA [47]. Pluronics have found a broad application in PDT due to the ease of solution preparation, their nontoxicity, targeted delivery and the effective solubilization of hydrophobic tetrapyrroles. We have previously shown successful solubilization of tetraphenylporphyrin derivatives by Pluronic F-127 [48-50]. In this regard, another task of this work was to estimate the effect of Pluronic F-127 micelles on the porphyrins' anti-HSV-1 activity.

\section{Results and Discussions}

\subsection{Synthesis of Porphyrins}

The literature mainly provides an investigation of cationic pyridinium porphyrins, analogues of the TMePyP $[25,27,32,37-40]$. In this work, the synthesized compounds 
differed in the length of aliphatic spacers between macrocycle and terminal cationic pyridinium groups ( 2 or 5 methylene units) (Figure 1, Scheme 1), in order to establish their structure/properties relationship. Porphyrins $\mathbf{2} \mathbf{a}, \mathbf{b}$ were synthesized using the method proposed by Lindsey [51], adapted in our laboratory for amphiphilic meso-arylporphyrins with alkyl substituents [52]. Pyrrole and substituted benzaldehydes $\mathbf{1} \mathbf{a}, \mathbf{b}$ were condensed with the formation of the bromine-substituted porphyrin precursors $\mathbf{2} \mathbf{a}, \mathbf{b}$ in $30-35 \%$ yields (Scheme 1 ). The target cationic porphyrins $\mathbf{3} \mathbf{a}, \mathbf{b}$ were obtained by boiling bromine-substituted porphyrins in pyridine to form a quaternary nitrogen atom in high yields (95-98\%). The structure of the purchased products was confirmed by UV-vis, ${ }^{1} \mathrm{H}$ and ${ }^{13} \mathrm{C}$ NMR spectroscopy, elemental analysis and LCMS (ESI) mass spectrometry (Figures S3-S12, Supplementary Information).

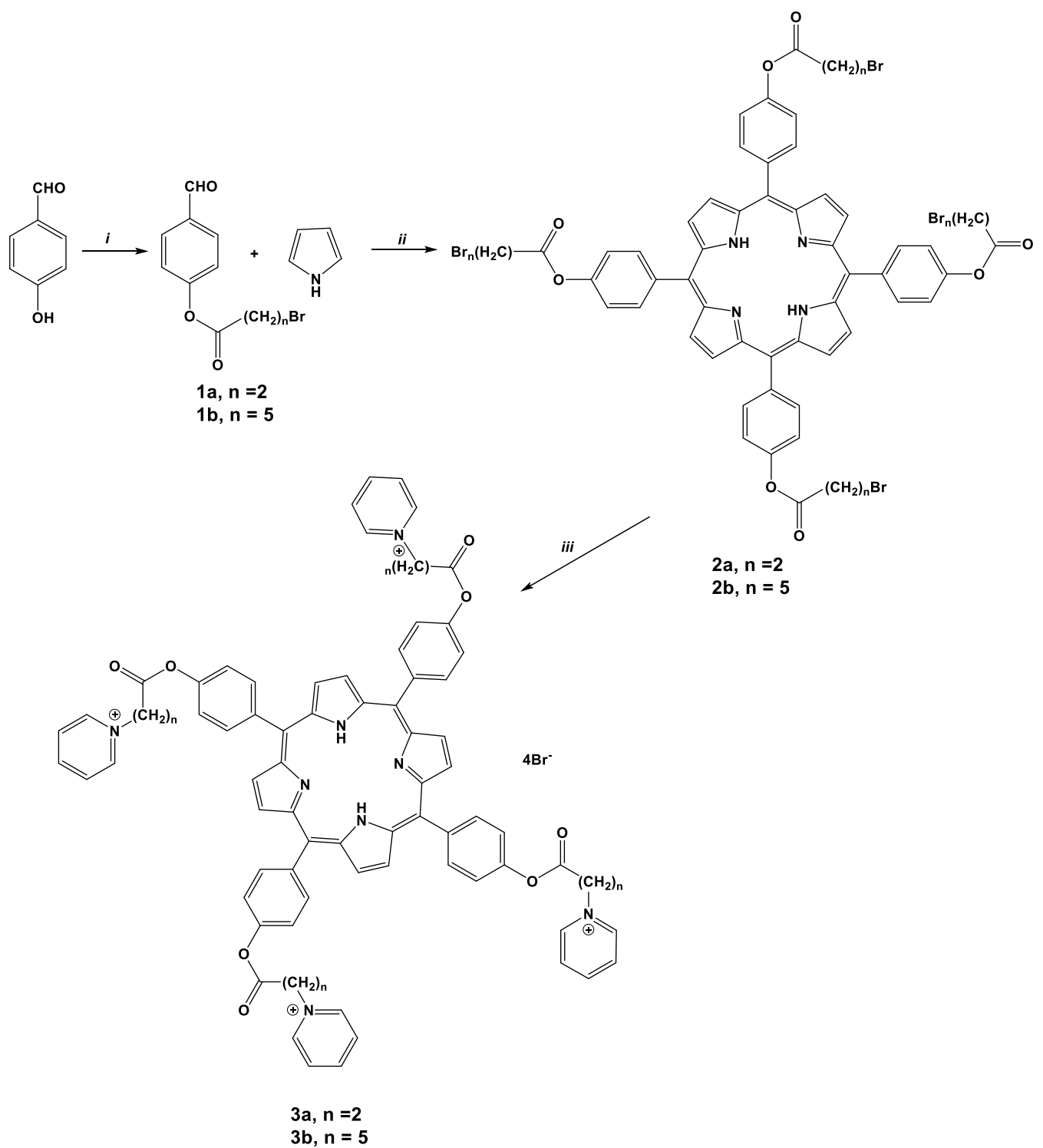

Scheme 1. The general scheme of cationic porphyrin synthesis. Reagents and reaction conditions: (i) 3-Bromopropionyl chloride (1a) or 6-Bromohexanoyl chloride (1b), $\mathrm{CHCl}_{3}, 0^{\circ} \mathrm{C}$; (ii) boron trifluoride etherate, chloroform, DDQ; yield $22 \%$ (2a) and 31\% (2b); (iii) pyridine, reflux, $4 \mathrm{~h}$, yield $93-95 \%$.

\subsection{Spectral Parameters and Photophysical Properties}

The electronic absorption spectra (EAS) for the free-base compounds $\mathbf{3} \mathbf{a}, \mathbf{b}$ showed the Soret band at $415-418 \mathrm{~nm}$ and four Q-bands in the region at 519-656 nm. The normalized 
UV-vis spectra, as well as the fluorescence spectra in DMSO and ethanol, are shown in Figures S1 and S2 (Supplementary Information). Stokes shift values, quantum fluorescence yield and $\log P$ coefficients are shown in Table 1 . Fluorescence quantum yields were measured as compared with 5,10,15,20-tetrakisphenylporphyrin (TPP) $\left(\Phi_{F}=0.11\right)$ and ZnTPP $\left(\Phi_{F}=0.033\right)$. For free-base compounds $3 \mathbf{a}, \mathbf{b}$ fluorescence quantum yields were similar at ca. 0.13 in DMSO and ca. 0.14, respectively. Octanol-water distribution coefficients were calculated using 1-n-octanol and phosphate-buffered saline (PBS), according to the method described in [53]. For the compounds $\mathbf{3 a}, \mathbf{b}$, negative $\log P$ ow values were obtained, indicating that photosensitizers had a higher solubility in water than in the organic phase. As expected, compound $3 \mathbf{a}$ was more hydrophilic $(\log P o w=-4.86)$ than $3 \mathbf{b}(\log P o w=-4.6)$. Such an effect can be associated with the increase in the number of methylene spacers in compound $\mathbf{3 b}$. The total data on photophysical parameters are presented in Table 1.

Table 1. Photophysical parameters and distribution coefficient of compounds $\mathbf{3 a}, \mathbf{b}$.

\begin{tabular}{|c|c|c|c|c|c|c|c|c|c|c|}
\hline \multirow{2}{*}{ No. } & \multicolumn{5}{|c|}{$\lambda_{\mathrm{abs}}(\mathrm{nm})\left(\varepsilon 10^{-3} \mathrm{~L} \mathrm{~mol}^{-1} \mathrm{~cm}^{-1}\right)^{\mathrm{a}}$} & \multicolumn{2}{|c|}{$\lambda_{\mathrm{em}}(\mathrm{nm})$} & \multirow[t]{2}{*}{$\Phi_{F}^{b}$} & \multirow[t]{2}{*}{ Stokes Shift } & \multirow[t]{2}{*}{$\log P^{c}$} \\
\hline & Soret & QI & QII & QIII & QIV & $Q(0,0)$ & $Q(0,1)$ & & & \\
\hline $3 a$ & 415 (312) & $512(14.5)$ & $546(6.2)$ & $590(3.7)$ & $645(3.5)$ & 651 & 721 & 0.14 & 238 & -4.86 \\
\hline $3 b$ & $418(328)$ & $513(13.37)$ & $548(6.07)$ & $592(3.64)$ & $648(3.56)$ & 652 & 723 & 0.13 & 236 & -4.6 \\
\hline
\end{tabular}

\subsection{The Inclusion of Porphyrins in Pluronic F127 Micelles}

Porphyrin macrocycles have demonstrated the tendency to aggregate in aqueous solutions due to the hydrophobic effect in combination with hydrogen and Van-der-Waals interactions [54-57]. Triblock copolymers, such as Pluronic, have been shown to reduce the self-aggregation of molecules and increase the solubility of porphyrins in aqueous media [58-60]. The obtained porphyrins 3a,b have been incorporated into Pluronic F-127 polymer micelles using the thin-film method [60]. The obtained solutions of porphyrins $3 \mathbf{a}, \mathbf{b}$ in PBS have been studied spectrophotometrically to exclude aggregation traits, such as the broadening of absorption bands [48,49]. As can be seen from the UV-vis spectra compounds, $\mathbf{3 a}, \mathbf{b}$ tended to aggregate in a buffer solution (broadening and with a decrease in the intensity of the Soret band with a bathochromic shift of $10 \mathrm{~nm}$ for $3 \mathbf{b}$ and $17 \mathrm{~nm}$ for 3a), compared with solutions of these porphyrins in DMSO and ethanol. The monomeric form for porphyrins $\mathbf{3} \mathbf{a}, \mathbf{b}$ was observed when using Pluronic F-127 micellar formulation (Figure 3a,b). The fluorescence spectra of $\mathbf{3 a}, \mathbf{b}$ in DMSO and Pluronic F-127 showed a slight decrease in the intensity of the bands; however, fluorescence quenching was not observed, suggesting that porphyrins $\mathbf{3} \mathbf{a}, \mathbf{b}$ were in monomeric form (Figure $3 c, d$ ).

The size of obtained micelles for the compounds $\mathbf{3} \mathbf{a}, \mathbf{b}$ was determined by the dynamic light scattering (DLS) method. The micelle size for compounds $\mathbf{3} \mathbf{a}, \mathbf{b}$ was $17.53 \mathrm{~nm}$ and $14.69 \mathrm{~nm}$, respectively, at concentrations of $3 \cdot 10^{-6} \mathrm{M}$ (Figure $4 \mathrm{a}, \mathrm{b}$ ). It has previously been reported that a similar micelle size increased the efficiency and circulation of the encapsulated drug in the blood due to the small scale, which avoided the capture of nanoparticles by the reticular endothelial system [61]. 


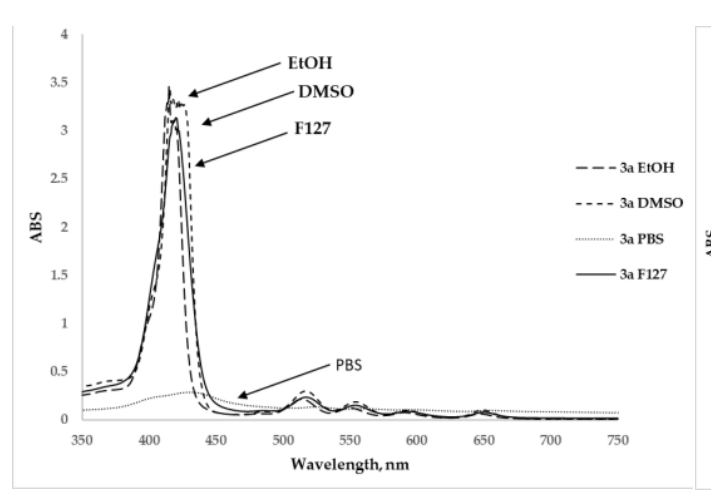

(a)

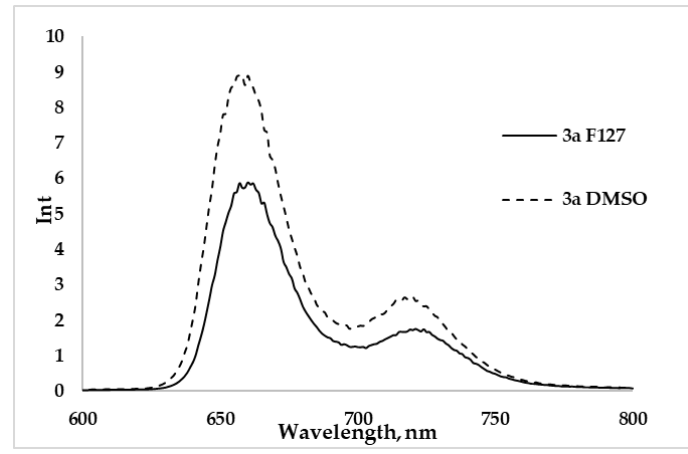

(c)

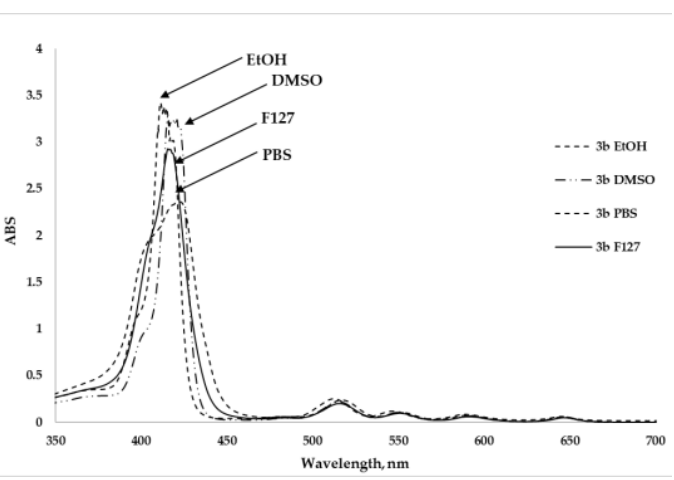

(b)

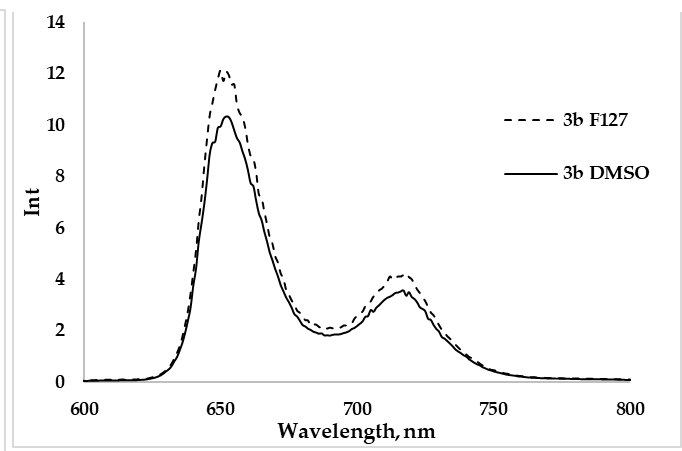

(d)

Figure 3. Electronic absorption spectra of compounds $3 \mathbf{a}(\mathbf{a})$ and $3 \mathbf{b}(\mathbf{b})\left(10^{-6} \mathrm{M}\right)$ and fluorescence spectra in DMSO and Pluronic F-127 at the excitation $\lambda \mathrm{ex}=415 \mathrm{~nm}$ for the compounds $3 \mathrm{a}(\mathbf{c})$ and $3 \mathbf{b}(\mathbf{d})\left(10^{-6} \mathrm{M}\right)$.

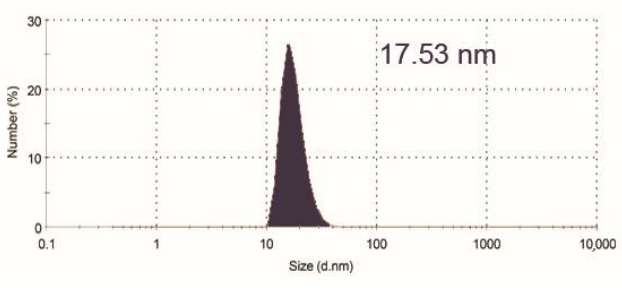

(a)

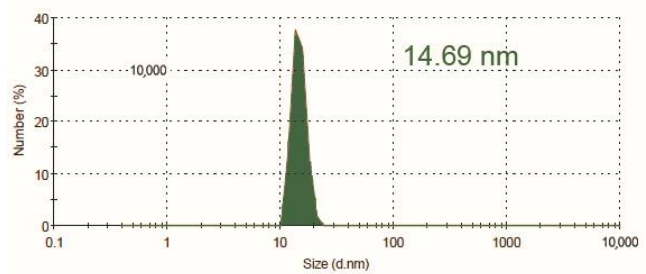

(b)

Figure 4. Particle sizes obtained by the dynamic light scattering (DLS) method for micellar solutions of compound 3a (a) and $3 \mathbf{b}(\mathbf{b})$ (concentration $\left.3 \cdot 10^{-6} \mathrm{M}\right)$.

\subsection{Virucidal Activity}

The ability of porphyrins to directly inactivate microorganisms may depend on their degree of solubility [50]. Therefore, in this work, the anti-HSV-1 activity of compounds $\mathbf{3 a}, \mathbf{b}$ and TMePyP was compared in PBS ( $\mathrm{pH}=7$ ) and Pluronic F-127 micelles.

Before testing antiviral activity, the effect of porphyrins dissolved in PBS and Pluronic F-127 on the viability of Vero cells was evaluated. Cells were incubated for $72 \mathrm{~h}$ using different concentrations of porphyrins $(0.39-100 \mu \mathrm{M})$. Viability was assessed using the MTT test (Figure S13, Table S1, Supplementary Information). The viability of Vero cells depends on the porphyrins' structure and formulation. The Pluronic F-127 and PBS formulations of compounds 3a and TMePyP showed low toxic effects: the maximum used concentrations of $100 \mu \mathrm{M}$ prevented the determination of $\mathrm{CC}_{50}$ (Table 2). Micellar formulation of $\mathbf{3 b}$ led to its higher toxicity, compared to the phosphate buffer, and $\mathrm{CC}_{50}$ values were $27.0 \mu \mathrm{M}$ and $43.0 \mu \mathrm{M}$, respectively. 
Table 2. $\mathrm{CC}_{50}$ and $\mathrm{IC}_{50}$ values of porphyrins dissolved in phosphate-buffered saline (PBS) or Pluronic F-127.

\begin{tabular}{ccccc}
\hline Compounds & \multicolumn{2}{c}{$\mathrm{CC}_{50}, \mu \mathrm{M}$} & \multicolumn{2}{c}{ IC $_{50}, \mu \mathrm{M}$} \\
\hline & PBS & F127 & PBS & F127 \\
\hline 3a & $>100$ & $>100$ & 53.6 & 99.8 \\
3b & 43.0 & 27.0 & 3.4 & 3.6 \\
TMePyP & $>100$ & $>100$ & 2.3 & 13.3 \\
\hline
\end{tabular}

Next, the virucidal effect of the drugs on HSV-1 in PBS and Pluronic F-127 was studied, in accordance with $\mathrm{CC}_{50}$ (Figure 5). The virucidal activity tests were performed by incubating HSV-1 with different concentrations of $\mathbf{3} \mathbf{a}, \mathbf{b}$ and TMePyP for $2 \mathrm{~h}$ at a temperature of $36.8^{\circ} \mathrm{C}$ and $5 \% \mathrm{CO}_{2}$. Untreated viral suspensions were used as a control. Then, samples were added to a Vero culture seeded in 96-well plates, and the residual virus content was evaluated by developing a cytopathic effect on the fourth day of cultivation.

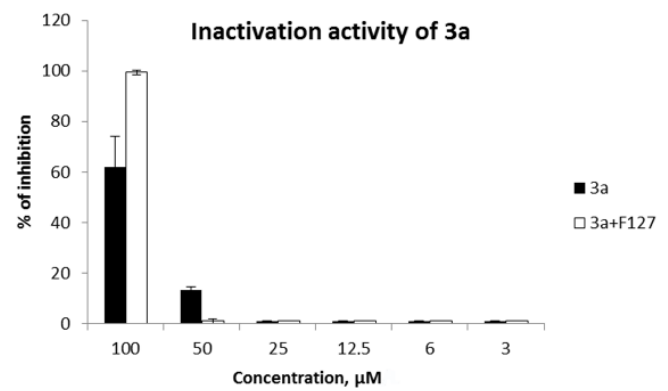

(a)

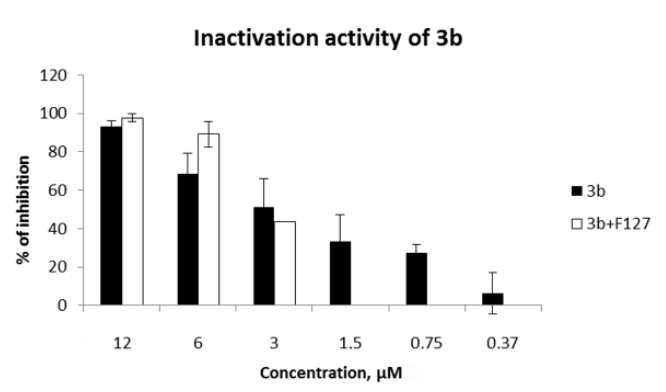

(b)

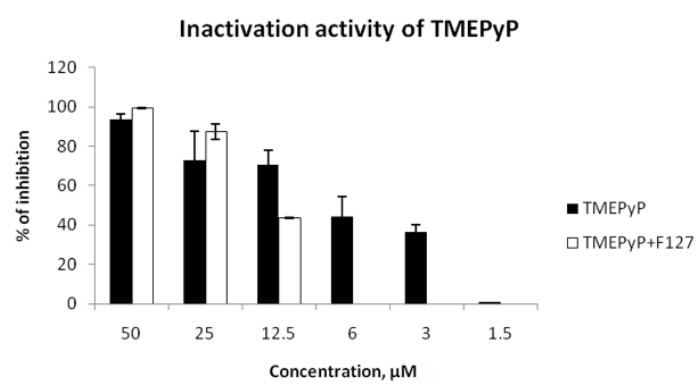

(c)

Figure 5. Virucidal activity of $\mathbf{3 a}(\mathbf{a}), \mathbf{3 b}(\mathbf{b}), \mathbf{T M e P y P}(\mathbf{c})$ dissolved in PBS and Pluronic F-127 regarding HSV-1. The results are presented as the virus titer percentage, with the porphyrin regarding the virus titer in control, which was taken as $100 \%$. Each point represents the mean \pm deviation of three experiments with three replicates.

The toxic concentration for compound 3a was $>100 \mu \mathrm{M}$. Porphyrin 3a showed a virucidal effect only at the maximum concentration of $100 \mu \mathrm{M}$, while the inhibition of the virus was more pronounced when using Pluronic F-127 micelles than with the use of PBS.

Porphyrin $3 \mathbf{b}$ exerted a virucidal effect starting at $12 \mu \mathrm{M}$. Antiviral activity of this compound depended on the solubilizing form used. Thus, dissolution of $3 \mathbf{b}$ in PBS revealed virucidal activity in concentrations from $12 \mu \mathrm{M}$ to $0.75 \mu \mathrm{M}$; its activity using Pluronic F-127 was at concentrations from $12 \mu \mathrm{M}$ to $3 \mu \mathrm{M}$.

The toxic concentration of TMePyP was $>50 \mu \mathrm{M}$; therefore, a concentration of $50 \mu \mathrm{M}$ and lower values were used to detect its virucidal effect. The virucidal effect of TMePyP in PBS was manifested in a wide range of concentrations, from $50 \mu \mathrm{M}$ to $3 \mu \mathrm{M}$; when using a TMePyP micellar solution, this effect was revealed in a narrower range of concentrations, 
from $50 \mu \mathrm{M}$ to $12.5 \mu \mathrm{M}$. For all studied compounds, dissolution in Pluronic F-127 exerted a virucidal effect on HSV-1 only at high concentrations, while, in PBS medium, porphyrins were active in a broader range of concentrations. Perhaps this is because porphyrins encapsulated in Pluronic micelles at low concentrations cannot contact virions.

\subsection{Antiviral Activity}

Porphyrin's antiviral action was then determined in terms of their effect on the HSV-1 replication stages in Vero cells. A two-part experiment was conducted to evaluate the influence of the obtained compounds on the early or late stages of replication (Figure 6). First, the effect of porphyrins on the initial stages of reproduction was estimated. Thus, HSV-1 at MOI 0.1 was adsorbed on Vero cells in a medium containing the studied porphyrin; then the cell monolayers were washed from the nonadsorbed virus, and porphyrins of the same concentration were introduced into the plate (1) (Vero Cells + HSV-1 + Porphyrin, left arrow. Figure 6), or the cell monolayers were washed from the nonadsorbed virus, and the medium without the test compound was introduced into the cell monolayers microwell plate (2) (Porphyrin + HSV-1 + Porphyrin medium, right arrow. Figure 6).

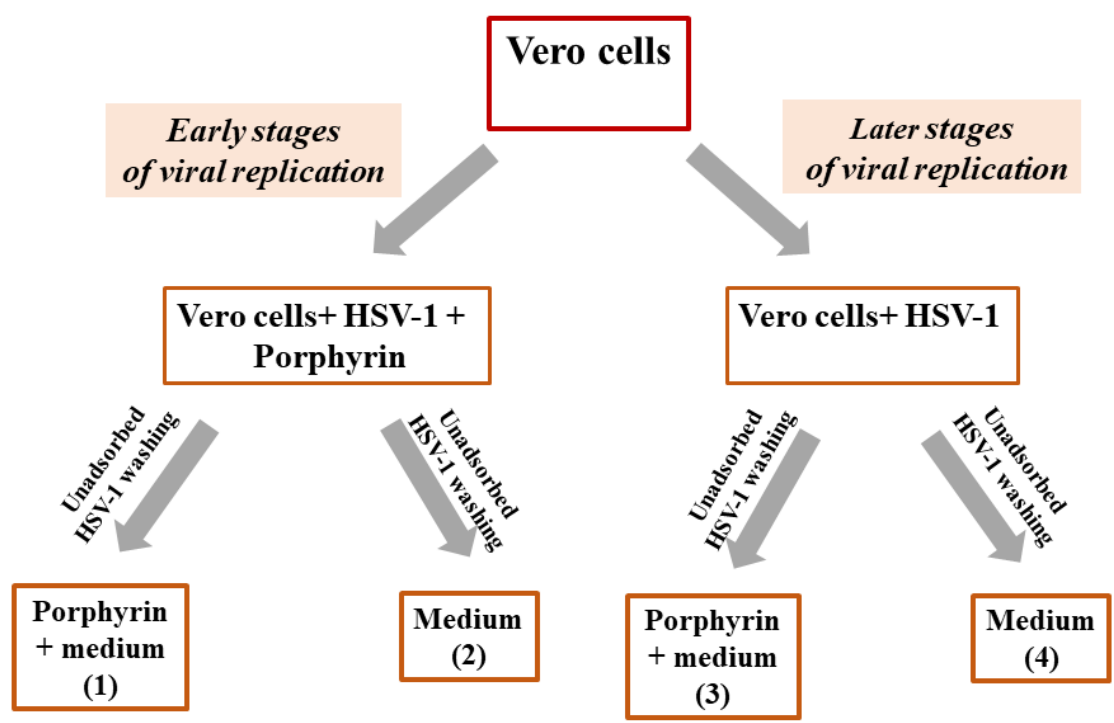

Figure 6. Experiment by the test compounds evaluation on the early or late stages of HSV-1 replication.

The influence of porphyrin antiviral activity on the HSV-1 postadsorption stages was simultaneously evaluated in this experiment. The studied compounds were introduced after HSV-1 adsorption on Vero cells and washing of nonadsorbed virus particles (3) (Vero Cells +HSV-1, left arrow. Figure 6) or, after virus adsorption and nonadsorbed virus particles washing, only the medium was introduced (control of virus reproduction) (4) (Vero Cells + HSV-1, right arrow. Figure 6). After the formation of a pronounced cytopathic effect of the virus in control cultures ( $48 \mathrm{~h}$ of cultivation), the virus infection activity of all the samples was determined by titration in a Vero cell culture (Figure 7). 


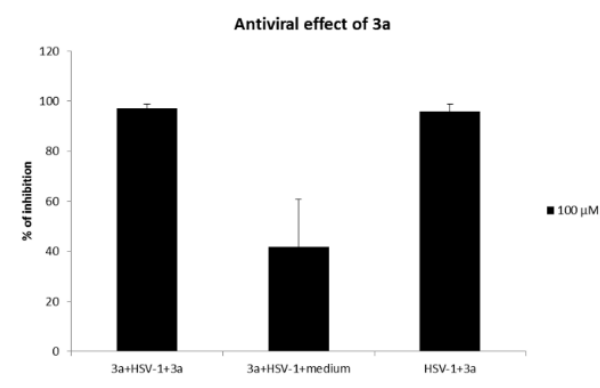

(a)

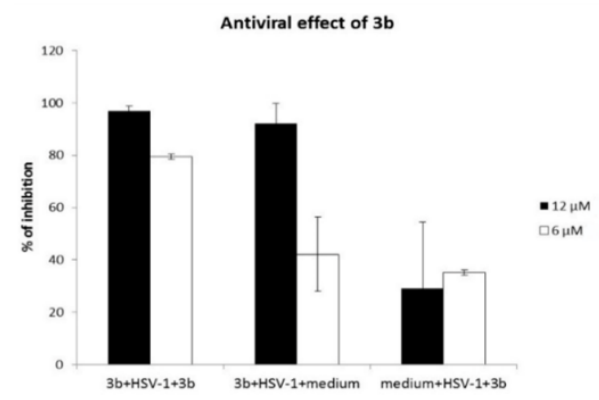

(b)

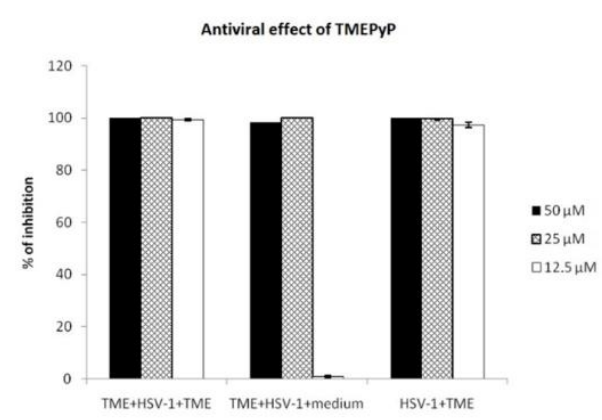

(c)

Figure 7. Inhibitory effect of porphyrins on the HSV-1 replication. The Vero cells were treated with compounds 3a $(100 \mu \mathrm{M})(\mathbf{a}), \mathbf{3 b}(12 \mu \mathrm{M}$ and $6 \mu \mathrm{M})(\mathbf{b})$ and TMePyP $(50 \mu \mathrm{M}, 25 \mu \mathrm{M}$ and $12.5 \mu \mathrm{M})$ (c) simultaneously with HSV-1 (MI 0.1$)$ or after HSV-1 (MI 0.1) adsorption. The results are presented as the percentage of the virus titer with porphyrin relative to its titer in the control (without porphyrin), which was taken as $100 \%$. Each bar represents the mean \pm deviation. Three experiments were performed with four repetitions.

Compound 3a suppressed the reproduction of the virus at the simultaneous introduction of the virus and the washing of the nonadsorbed virus $(3 \mathbf{a}+\mathrm{HSV}-1+\mathbf{3 a})$ or in the post-infection study (HSV-1 + 3a) (Figure 7). Apparently, 3a acts on both the initial and postadsorption stages of virus replication. The introduction of $3 \mathbf{a}$ into the medium only at the cell infection stage (3a + HSV-1 + media) did not significantly suppress the reproduction of the virus.

The TMePyP compound also affected both the initial and late stages of virus replication. In addition, for this compound, a dose-dependent effect was noted: the simultaneous addition of TMePyP at high concentrations $(50 \mu \mathrm{M}$ and $25 \mu \mathrm{M})$ with the virus completely suppressed its replication (Figure 7). Conversely, a lower concentration of TMePyP $(12 \mu \mathrm{M})$ did not suppress the HSV-1 reproduction when the porphyrin was introduced at the stage of virus adsorption.

Porphyrin $\mathbf{3 b}$ had a greater effect on the early stages of virus reproduction $(3 \mathbf{b}+\mathrm{HSV}-1+\mathbf{3 b}$, $3 \mathbf{b}+$ HSV-1 + medium), since suppression of reproduction was more pronounced when treating cells with porphyrin at the stage of virus adsorption on Vero cells (Figure 7). The effect was less pronounced at low concentrations of $\mathbf{3 b}$. Summarizing the experimental results, we can conclude that the final effect of the substances on HSV-1 was associated with both virucidal and antiviral effects.

\section{Materials and Methods}

\subsection{Cells}

African green monkey kidney cells (Vero) were cultured in DMEM (Dulbecco's Modified Eagle Medium) supplemented with 5\% fetal calf serum (FCS) and $50 \mu \mathrm{g} / \mathrm{mL}$ gentamycin, both purchased from Gibco (Thermo Fisher Scientific, Inc., Waltham, MA, USA), and maintained at $36.8{ }^{\circ} \mathrm{C}$ in $5 \% \mathrm{CO}_{2}$ atmosphere. 


\subsection{Virus}

HSV-1 (strain RD from WHO laboratory, Geneva, Switzerland) was propagated in Vero cells after a multiplicity of infection (MOI) of $0.1 \mathrm{TCID}_{50} /$ cell in DMEM- $\%$ fetal calf serum (FCS) for $20 \mathrm{~h}$. Then the supernatant was centrifuged at $700 \times g$ to remove cellular debris and stored in aliquots at $-30^{\circ} \mathrm{C}$. To determine viral activity, tenfold dilutions of the virus were applied to the Vero cell monolayers in 96-well plates, and, after 4 days of cultivation at $36.8^{\circ} \mathrm{C}$ in $5 \% \mathrm{CO}_{2}$ atmosphere, titers were calculated based on the development of $\mathrm{CPE}$ (Cytopathic effect).

\subsection{Cell Viability}

Cell viability was assessed by MTT reduction assay. Briefly, confluent monolayer Vero cells in 96-well plates (15000 cells/well) were incubated for $72 \mathrm{~h}$ with different concentrations of the compounds ranging from $0.39 \mu \mathrm{M}$ to $100 \mu \mathrm{M}$ in DMEM- $1 \%$ FCS at $36.8^{\circ} \mathrm{C}$ in $5 \% \mathrm{CO}_{2}$ atmosphere. Next, cells were incubated for $1 \mathrm{~h}$ with $1.0 \mathrm{mg} / \mathrm{mL}$ of $3-(4,5-$ dimethylthiazol-2-y1)-2,5-diphenyltetrazolium bromide (MTT, PanEco, Moscow, Russia) at $36.8{ }^{\circ} \mathrm{C}$, and then the solution was removed, and precipitated formazan was diluted in DMSO (PanEco, Moscow, Russia). The solution was read on a spectrophotometer at $540 \mathrm{~nm}$. For each concentration, the average cell viability was calculated from the data of three experiments with three replicates each and was expressed as a percentage compared to the untreated cells $(100 \%)$.

\subsection{Virucidal Effect}

HSV-1 at tenfold dilutions DMEM-1\% FCS $(900 \mu \mathrm{L})$ was incubated with different concentration of the compounds $(100 \mu \mathrm{L})$ at the final concentration ranging from $3 \mu \mathrm{M}$ to $100 \mu \mathrm{M}$ in DMEM-1\% FCS or without of compound, each sample in volume $1 \mathrm{~mL}$, for $2 \mathrm{~h}$ at $36.8^{\circ} \mathrm{C}$ in $5 \% \mathrm{CO}_{2}$ atmosphere. After treatment, the samples were applied to the Vero cell (the day before, cells were seeded at the rate of 15,000 cells/well in 100 of DMEM- $5 \%$ FCS in 96-well plates) monolayers in 96-well plates ( $100 \mu \mathrm{L} /$ well), and, after 4 days of cultivation at $36.8^{\circ} \mathrm{C}$ in $5 \% \mathrm{CO}_{2}$ atmosphere, titers were calculated based on the development of $\mathrm{CPE}$, and the inhibitory activity of each compounds was calculated in relation to the control (HSV-1 without compounds). Data are reported as means of three independent assays, each run in triplicate.

\subsection{Influence of the Compounds on Virus Yield during Infection}

Four variants were used to test compound efficiency in controlling development of infection in Vero cells. The Vero cells were seeded in 24-well plate in $1 \mathrm{~mL}$ of DMEM-5\% FCS. (1) The cell monolayers were treated simultaneously with HSV-1 (MOI 0.1) in DMEM$1 \%$ FCS $(900 \mu \mathrm{L})$ and investigated compounds in DMEM- $1 \%$ FCS $(100 \mu \mathrm{L})$ for $2 \mathrm{~h}$ at $36.8^{\circ} \mathrm{C}$ in $5 \% \mathrm{CO}_{2}$ atmosphere; then the cell monolayers were washed from the nonadsorbed virus and treated with $900 \mu \mathrm{L}$ of DMEM-1\%FCS and the same concentrations of compounds $(100 \mu \mathrm{L})$. (2) The cell monolayers were treated simultaneously with HSV-1 (MOI 0.1) DMEM$1 \%$ FCS $(900 \mu \mathrm{L})$ and compounds DMEM-1\%FCS $(100 \mu \mathrm{L})$ for $2 \mathrm{~h}$ at $36.8{ }^{\circ} \mathrm{C}$ in $5 \% \mathrm{CO}_{2}$ atmosphere, and then the cell monolayers were washed from the nonadsorbed virus, after which only DMEM-1\% FCS (1 mL) was added. (3) The cell monolayers were treated with HSV-1 (MOI 0.1) DMEM-1\% FCS $(900 \mu \mathrm{L})$ and DMEM-1\% FCS $(100 \mu \mathrm{L})$ for $2 \mathrm{~h}$ at $36.8^{\circ} \mathrm{C}$ in $5 \% \mathrm{CO}_{2}$ atmosphere and washed from the nonadsorbed virus; then DMEM- $1 \%$ FCS $(900 \mu \mathrm{L})$ and the same compounds in DMEM-1\% FCS $(100 \mu \mathrm{L})$ were added. (4) Control: the cell monolayers were treated with HSV-1 (MOI 0.1) in DMEM-1\% FCS $(900 \mu \mathrm{L})$, and DMEM- $1 \%$ FCS $(100 \mu \mathrm{L})$ was added for $2 \mathrm{~h}$ at $36.8{ }^{\circ} \mathrm{C}$ in $5 \% \mathrm{CO}_{2}$ atmosphere and washed from the nonadsorbed virus, and then DMEM- $1 \%$ FCS $(1 \mathrm{~mL})$ was added. In all variants, the treated cells were then incubated at $36.8^{\circ} \mathrm{C}$ in $5 \% \mathrm{CO}_{2}$ atmosphere.

After the development of a cytopathic effect in control cultures (HSV-1 + medium, $48 \mathrm{~h}$ ), the virus content was determined in samples of the culture medium by applying ten-fold dilutions $(100 \mu \mathrm{L})$ on a monolayers of Vero cells in wells of 96-well plates. After 
three days, virus titers were counted, and the percentage of inhibition regarding the titer of the virus in the control, which was taken as $100 \%$, was determined. The results were presented as the average of three experiments of four replays.

\subsection{Synthesis}

\subsubsection{Reagents}

All reagents were commercially available and used as received if not specially mentioned. All solvents were dried, as recommended in standard procedures. Chromatographic purifications were carried out on silica gel (Silica 60 0.04-0.063 mm/230-400 mesh, Macherey-Nagel, Dueren, Germany). Thin-layer chromatography was performed using aluminum sheets coated with silica gel 60 F254 (Macherey-Nagel, Dueren, Germany). $\mathrm{TMePyP}$ was received according to the known procedure [62,63].

\subsubsection{Measurements}

NMR $\left({ }^{1} \mathrm{H}\right.$ and $\left.{ }^{13} \mathrm{C}\right)$ spectra of the test solutions in $\mathrm{CDCl}_{3}$ or $\left(\mathrm{CD}_{3} \mathrm{OD}\right)$ were recorded on a Bruker MSL-300 pulse Fourier transform spectrometer (Bruker, Billerica, MA, USA) at frequencies of 300.3 and $75.49 \mathrm{MHz}$, respectively, with internal deuterium stabilization. Tetramethylsilane was used as an external standard. IR spectra $\left(4000-500 \mathrm{~cm}^{-1}\right)$ were recorded on Infralyum FT 02 Fourier spectrometer (Lumex Instruments Research and Production Company, Moscow, Russia) with a resolution of $1 \mathrm{~cm}^{-1}$. Samples were prepared as $\mathrm{KBr}$ tablets. Dynamic light scattering was measured using Malvern Zetasizer Nano ZS (Malvern, United Kingdom). Elemental analysis was performed on a C, H, N, S FLASH EA 112 analyzer of Termo Finnigan (Monza, Italy). Mass spectra were recorded using an 1100 LCMSD liquid chromatograph (Agilent Technologies, Santa Clara, CA, USA) equipped with a mass spectrometric chemical ionization detector at atmospheric pressure (HIAD, APCI, ESI) and with a UV spectrophotometric detector (DAD). Chromatographic separation was carried out on a Peekescientific $50 \times 4.6 \mathrm{~mm}$ Hi-QC18 column (Glasgow, United Kingdom) with silica gel modified with an octadecyl phase $\left(\mathrm{C}_{18}\right)$ with a sorbent particle size of $5 \mu \mathrm{m}$ and a pore size of $50 \AA$ (eluent A: $2.5 \%$ acetonitrile, $0.1 \%$ trifluoroacetic acid/water; eluent B: $0.1 \%$ trifluoroacetic acid/acetonitrile; from $10 \%$ eluent B linear gradient increase in 2.9 min to $100 \%$ B, then washing the column with $100 \%$ eluent B for $1 \mathrm{~min}$, then balancing to the initial conditions for $0.1 \mathrm{~min}$; mobile phase velocity $4 \mathrm{~mL} / \mathrm{min}$ ). Electronic absorption spectra were recorded using Shimadzu UV-1800 (Kioto, Japan) spectrophotometer at room temperature in quartz cells with an optical path length of $10 \mathrm{~mm}$. Steady-state fluorescence measurements were carried out using Cary Eclipse (Agilent Technologies, Santa Clara, CA, USA) luminescence spectrometer at room temperature in $10 \mathrm{~mm}$ quartz cells with the excitation wavelength corresponding to the absorption maximum of the porphyrin in the Soret band region $(415 \mathrm{~nm})$.

\subsubsection{General Procedure for the Substituted Benzaldehydes 1a,b Preparation}

To a solution of $p$-hydroxybenzaldehyde $1.2 \mathrm{~g}(9.83 \mathrm{mmol})$ and DMAP $0.9 \mathrm{~g}(7.37 \mathrm{mmol})$ in dichloromethane $(25 \mathrm{~mL})$, a solution of $2.00 \mathrm{~g}(11.8 \mathrm{mmol})$ 3-bromopropionyl chloride (a) or $2.52 \mathrm{~g}$ (11.8 mmol) 6-bromohexanoyl chloride (b) in $10 \mathrm{~mL}$ of dichloromethane $(20 \mathrm{~mL})$ were added dropwise during $30 \mathrm{~min}$ at $0{ }^{\circ} \mathrm{C}$. After $30 \mathrm{~min}$, the mixture was additionally stirred at room temperature for $24 \mathrm{~h}$. Excess of solvent was removed under reduced pressure. The reaction mass was purified by column chromatography on silica gel G 60 (dichloromethane: hexane $=4: 1$ ).

4-(3-Bromo-n-propanoyloxy)benzaldehyde (1a). Yield: $3.58 \mathrm{~g}(70 \%)$. $\mathrm{Rf} 0.6\left(\mathrm{CH}_{2} \mathrm{Cl}_{2}\right)$; $\operatorname{IR}\left(v, \mathrm{~cm}^{-1}\right)$ : 2928, $2849\left(\mathrm{CH}_{2}\right)_{2}, 1675(\mathrm{C}=\mathrm{O}), 1467(\mathrm{Ar}), 1160,1138(\mathrm{C}-\mathrm{O}), 642,550(\mathrm{C}-\mathrm{Br})$. ${ }^{1} \mathrm{H} \mathrm{NMR}\left(\mathrm{CDCl}_{3}, \delta, \mathrm{ppm}\right): 2.97\left(2 \mathrm{H}, \mathrm{t}, J=6.65 \mathrm{~Hz}, \mathrm{CH}_{2} \mathrm{Br}\right), 3.55\left(2 \mathrm{H}, \mathrm{t}, J=6.65 \mathrm{~Hz}, \mathrm{OCOCH}_{2}\right)$ $7.46(2 \mathrm{H}, \mathrm{d}, J=8.40 \mathrm{~Hz}, 3,5-(\mathrm{ArH})), 7.96(2 \mathrm{H}, \mathrm{d}, J=8.70 \mathrm{~Hz}, 2,6-(\mathrm{ArH})), 9.99(1 \mathrm{H}, \mathrm{s}, \mathrm{CHO})$.

4-(6-Bromo-n-hexanoyloxy)benzaldehyde (1b). Yield $2.35 \mathrm{~g}(80 \%), \quad \mathrm{Rf} \quad 0.3$, (dichloromethane: hexane = 7:3); IR $\left(v, \mathrm{~cm}^{-1}\right)$ : 2926, $2848\left(\mathrm{CH}_{2}\right)_{5}, 1676(\mathrm{C}=\mathrm{O}), 1467$ (Ar), 1160, 1138 (C-O), 642, 550 (C-Br). ${ }^{1} \mathrm{H}$ NMR: $\left(\mathrm{CDCl}_{3}, \delta\right.$, ppm): 1.55-1.65 (2H, m, 
$\left.\mathrm{OCO}\left(\mathrm{CH}_{2}\right)_{2} \mathrm{CH}_{2}\left(\mathrm{CH}_{2}\right)_{2} \mathrm{Br}\right), 1.77-1.84\left(2 \mathrm{H}, \mathrm{m}, \mathrm{OCOCH}_{2} \mathrm{CH}_{2}\right), 1.89-1.97\left(2 \mathrm{H}, \mathrm{m}, \mathrm{CH}_{2} \mathrm{CH}_{2} \mathrm{Br}\right)$, $2.64\left(2 \mathrm{H}, \mathrm{t}, J=7.24 \mathrm{~Hz} \mathrm{OCOCH}_{2}\right), 3.46\left(2 \mathrm{H}, \mathrm{t}, J=6.69 \mathrm{~Hz}, \mathrm{CH}_{2} \mathrm{CH}_{2} \mathrm{Br}\right) 7.51(2 \mathrm{H}, \mathrm{d}, 2,6-(\mathrm{ArH}))$, $7.96(2 \mathrm{H}, \mathrm{d}, 3,5-(\mathrm{ArH})), 10.01(1 \mathrm{H}, \mathrm{s}, \mathrm{CHO})$.

\subsubsection{General Procedure for the Porphyrins $\mathbf{2} \mathbf{a}, \mathbf{b}$ Preparation}

Pyrrole $0.1 \mathrm{~g}$ (1.42 $\mathrm{mmol})$ and 4-(3-bromo-n-propanoyloxy)benzaldehyde $0.38 \mathrm{~g}$ (1.50 mmol) 1a or 4-(6-bromo- $n$-hexanoyloxy)benzaldehyde $0.45 \mathrm{~g}$ (1.50 mmol) $\mathbf{1 b}$ were dissolved in chloroform $(100 \mathrm{~mL})$. The reaction mixture was saturated with argon and stirred at room temperature for $5 \mathrm{~min}$, after which $20 \mu \mathrm{L}(0.15 \mathrm{mmol})$ of boron trifluoride etherate and $200 \mu \mathrm{L}$ of absolute ethanol were added. The reaction mass was stirred under inert atmosphere at room temperature for $2 \mathrm{~h}$. After that, argon was removed and $0.3 \mathrm{~g}$ DDQ $(1.35 \mathrm{mmol})$ was added, and the resulting mixture was stirred at room temperature for $4 \mathrm{~h}$. The reaction mixture was concentrated under reduced pressure. Oligomeric products were separated by flash chromatography on silica gel G 60 eluted with chloroform. The target product was purified by column chromatography on silica gel G 60 eluted with a system of chloroform:hexane $=4: 1$.

5,10,15,20-tetrakis(4-(3-bromo-n-propanoyl)oxyphenyl)porphyrin (2a). Yield: $0.09 \mathrm{~g}$ (22\%). Rf $0.5\left(\mathrm{CH}_{2} \mathrm{Cl}_{2}\right)$. EAS, $\lambda \max , \mathrm{nm}\left(\varepsilon \times 10^{-3}\right)$ : 417 (318.14); 515.5 (14.89); 550.8 (6.15); 590.1 (3.49); 646.5 (3.01). ${ }^{1} \mathrm{H} \mathrm{NMR}\left(\mathrm{CDCl}_{3}, \delta, \mathrm{ppm}\right):-2.74$ (2H, c, NH-pyrrole), $3.38\left(8 \mathrm{H}, \mathrm{t}, J=6.65 \mathrm{~Hz}, \mathrm{OCOCH}_{2} \mathrm{CH}_{2} \mathrm{Br}\right), 3.86\left(8 \mathrm{H}, \mathrm{t}, J=6.69 \mathrm{~Hz}, \mathrm{OCOCH}_{2} \mathrm{CH}_{2} \mathrm{Br}\right), 7.57$ $(8 \mathrm{H}, \mathrm{d}, J=8.34 \mathrm{~Hz}, 3,5-(\mathrm{ArH})), 8.30(8 \mathrm{H}, \mathrm{d}, J=8.30 \mathrm{~Hz}, 2,6-(\mathrm{ArH})), 8.95(8 \mathrm{H}, \mathrm{s}, \mathrm{CH}-$ pyrrole). Elemental analysis: found, \%: C 56.18; $\mathrm{H} 3.25 ; \mathrm{N} 4.75 . \mathrm{C}_{56} \mathrm{H}_{42} \mathrm{~N}_{4} \mathrm{O}_{8} \mathrm{Br}_{4}$; calculated, $\%$ : C 55.20; H 3.47; N 4.60.

5,10,15,20-tetrakis(4-(6-bromo-n-hexanoyl)oxyphenyl)porphyrin (2b). Yield $0.15 \mathrm{~g}$ (31\%); Rf 0.8 (CHCl3). EAS, $\lambda \max , \mathrm{nm}\left(\varepsilon \times 10^{-3}\right)$ : 419.8 (321); 514.4 (15.28); 549.8 (5.96); 589 (3.63); 645.6 (3.43). ${ }^{1} \mathrm{H} \mathrm{NMR}\left(\mathrm{CDCl}_{3}, \delta, \mathrm{ppm}\right.$.): $1.56\left(8 \mathrm{H}, \mathrm{m}, \mathrm{CH}_{2} \mathrm{CH}_{2} \mathrm{Br}\right), 1.98-2.05(16 \mathrm{H}, \mathrm{m}$, $\left.\mathrm{OCOCH}_{2}\left(\mathrm{CH}_{2}\right)_{2}\right), 2.79\left(8 \mathrm{H}, \mathrm{t}, J=7.34 \mathrm{~Hz}, \mathrm{OCOCH}_{2}\right), 3.52\left(8 \mathrm{H}, \mathrm{t}, J=6.69 \mathrm{~Hz}, \mathrm{CH}_{2} \mathrm{CH}_{2} \mathrm{Br}\right)$, $7.54(8 \mathrm{H}, \mathrm{d}, J=8.44 \mathrm{~Hz}, 3.5-(\mathrm{ArH})), 8.20(8 \mathrm{H}, \mathrm{d}, J=8.48, \mathrm{~Hz} 2.6-(\mathrm{ArH}), 8.88(8 \mathrm{H}, \mathrm{s}, \mathrm{CH}$ pyrrole). ${ }^{13} \mathrm{C} \mathrm{NMR}\left(\mathrm{CDCl}_{3} \delta\right.$, ppm): 171.7, 145.5, 145.5, 138.6, 134.5, 127.6, 119.5, 61.0, 33.3, 30.8, 25.0, 23.6. Elemental analysis: found, \%: C 58.18; $\mathrm{H} 4.65 ; \mathrm{N} 4.10 . \mathrm{C}_{68} \mathrm{H}_{66} \mathrm{~N}_{4} \mathrm{O}_{8} \mathrm{Br}_{4}$; calculated, \%: C 58.89; H 4.80; N 4.04 .

\subsubsection{General Procedure for the Preparation of Porphyrins $\mathbf{3 a}, \mathbf{b}$}

The initial porphyrin $\mathbf{2 a}(0.02 \mathrm{~g}, 0.016 \mathrm{mmol})$ or $\mathbf{2 b}(0.05 \mathrm{~g}, 0.036 \mathrm{mmol})$ was dissolved in dry pyridine and boiled for $3 \mathrm{~h}$. The formed precipitate was filtered and washed with chloroform; the solvent was removed under reduced pressure. The reaction product was isolated by recrystallization from diethyl ether. Yield 95-97\%.

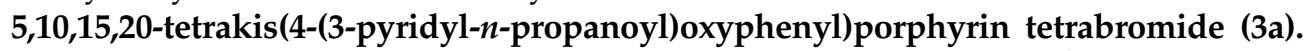
Yield: $0.019 \mathrm{~g}(95 \%)$. Rf $0.2\left(\mathrm{CH}_{2} \mathrm{Cl}_{2}\right.$ :EtOAc $\left.=1: 1\right)$; EAS, $\lambda \max , \mathrm{nm}\left(\varepsilon \times 10^{-3}\right): 415.5(312.5)$; 512.5 (14.5); 547.5 (6.2); 589 (3.7); 645.5 (3.5). ${ }^{1} \mathrm{H}$ NMR (CD $3 \mathrm{OD}, \delta, \mathrm{ppm}$.): 3.68 (8H, t, $J=6.16 \mathrm{~Hz}$, $\left.\mathrm{OCOCH}_{2}\right), 5.15\left(8 \mathrm{H}, \mathrm{t}, J=6 \mathrm{~Hz}, \mathrm{CH}_{2} \mathrm{CH}_{2} \mathrm{Py}\right), 7.35(8 \mathrm{H}, \mathrm{d}, J=8.13 \mathrm{~Hz}, 3,5-(\mathrm{ArH})), 7.94(8 \mathrm{H}$, $\mathrm{d}, J=8 \mathrm{~Hz}, 2,6-(\mathrm{ArH})), 8.19(8 \mathrm{H}, \mathrm{t}, J=7.72 \mathrm{~Hz}, 3,5-\mathrm{Py}), 8.59-8.69$ (12H, m, 4-Py ${ }^{+} \mathrm{CH}$ pyrrole), $9.25(8 \mathrm{H}, \mathrm{d}, J=5.66 \mathrm{~Hz}, 2,6-\mathrm{Py}) .{ }^{13} \mathrm{C} \mathrm{NMR}$ (CD $\mathrm{CDD}_{3}$, ppm): 171.4, 150.7, 145.8, 144.7, 139.4, 135.0, 128.3, 119.6, 119.2, 60.7, 30.2, 26.1. Elemental analysis: found, \%: C 60.98; H 4.13; N 7.09, $\mathrm{C}_{76} \mathrm{H}_{62} \mathrm{~N}_{8} \mathrm{O}_{8} \mathrm{Br}_{4}$ calculated, \%: C 59.47; $\mathrm{H} 4.07$; N 7.30. LCMS (ESI) $m / z: 302.1\left[\mathrm{M}^{+} 4 \mathrm{Br}^{-}\right]^{+}$; the molecular formula of $\mathrm{C}_{76} \mathrm{H}_{62} \mathrm{~N}_{8} \mathrm{O}_{8}$ requires 303.6.

5,10,15,20-tetrakis(4-(6-pyridyl-n-hexanoyl)oxyphenyl)porphyrin tetrabromide (3b). Yield $46 \mathrm{mg}(93 \%)$. EAS, $\lambda$ max, $\mathrm{HM}\left(\varepsilon \times 10^{-3}\right),\left(\mathrm{CH}_{3} \mathrm{OH}\right): 415$ (328); 513 (13.37), 546 (6.07), 589 (3.64), 645 (3.56). ${ }^{1} \mathrm{H}$ NMR (CD $\mathrm{OD}, \delta, \mathrm{ppm}$ ): $1.72\left(8 \mathrm{H}, \mathrm{m}, \mathrm{OCO}\left(\mathrm{CH}_{2}\right)_{2} \mathrm{CH}_{2}\left(\mathrm{CH}_{2}\right)_{2} \mathrm{Py}\right)$, $2.01\left(8 \mathrm{H}, \mathrm{m}, \mathrm{OCOCH}_{2} \mathrm{CH}_{2}\right), 3.35\left(8 \mathrm{H}, \mathrm{m}, \mathrm{CH}_{2} \mathrm{CH}_{2} \mathrm{Py}\right), 3.99\left(8 \mathrm{H}\right.$, br s, $\left.\mathrm{OCOCH}_{2}\right), 4.36(8 \mathrm{H}$, m, $\left.\mathrm{CH}_{2} \mathrm{CH}_{2} \mathrm{Py}\right), 7.04(8 \mathrm{H}, \mathrm{m}, 3,5-(\mathrm{ArH})), 7.83(8 \mathrm{H}, \mathrm{d}, 2,6-(\mathrm{ArH})), 7.96$ (8H, m, 3,5-Py), 8.40 (4H, m, 4-Py), 8.71 (8H, br. s, pyrrole), 8.82 (8H, s, 2,6-Py). $\left.{ }^{13} \mathrm{C} \mathrm{NMR} \mathrm{(} \mathrm{CDCl}_{3} \delta, \mathrm{ppm}\right): 172.4$, 150.7, 146.1, 144.5, 138.6, 134.8, 127.6, 119.8, 118.7, 61.6, 33.3, 30.5, 25.0, 23.6. Elemental analysis: 
found, \%: C 62.58; $\mathrm{H}$ 5.35; N 6.45, $\mathrm{C}_{88} \mathrm{H}_{86} \mathrm{~N}_{8} \mathrm{O}_{8} \mathrm{Br}_{4}$ calculated, \%: C 62.05; $\mathrm{H}$ 5.09; N 6.58. LCMS (ESI) $m / z: 345.7\left[\mathrm{M}^{+}-4 \mathrm{Br}\right]^{+}$; the molecular formula of $\mathrm{C}_{88} \mathrm{H}_{86} \mathrm{~N}_{8} \mathrm{O}_{8}$ requires 345.66.

\subsection{6. $n$-Octanol/PBS Partition Coefficients}

The distribution coefficient was measured using 1-n-octanol and phosphate buffered saline (PBS), which were presaturated with each other by the described method [53]. A portion of porphyrin $(1-1.5 \mathrm{mg})$ was added to saturated solutions of 1 - $n$-octanol ( $3 \mathrm{~mL})$ and PBS ( $3 \mathrm{~mL})$, sonicated and shaken for $30 \mathrm{~min}$, then centrifuged to separate the layers. The absorption of each layer was measured spectrophotometrically in the region of the Soret band. Partition coefficients were calculated as the ratio between absorption in the Soret band of photosensitizers in organic and aqueous phase and the dilution factors for the organic and aqueous layers, according to the aforementioned method.

\subsection{Statistical Analysis}

Graphing, as well as statistical processing of the results, were performed using Microsoft Excel 2007 (Albuquerque, NM, USA) and GraphPadPrism v. 7.00 (San Diego, CA, USA). To assess the statistical significance, we used a two-pair $t$-test.

\section{Conclusions}

A simple and convenient approach for the synthesis of new cationic meso-arylporphyrins has been proposed. For solubilization of the monomeric form of porphyrins Pluronic F-127, polymer micelles were used. It has been shown that the studied cationic porphyrins, which are potential photosensitizers, exhibited a pronounced antiherpetic effect without additional light exposure. Porphyrin 3a was found to have low toxicity and showed an antiviral effect only at high concentrations, while an increase in the length of aliphatic spacer sites between the macrocycle and cationic centers in compound $\mathbf{3 b}$ increased the toxicity of porphyrin. In this case, porphyrin $\mathbf{3 b}$ exhibited an antiviral effect at lower concentrations and in a wider range of concentrations. The value of $\mathrm{IC}_{50}, \mu \mathrm{M} / \mathrm{L}$ for porphyrin $3 \mathbf{b}$ was found to be more than 10 times lower than $\mathrm{CC}_{50}, \mu \mathrm{M} / \mathrm{L}$, which indicates the prospects of this substance for further studies. The known cationic porphyrin TMePyP exhibited antiviral activity against HSV-1 in a wide range of concentrations. Compounds $3 \mathbf{a}, \mathbf{3 b}$ and TMePyP showed both a virucidal effect and an inhibitory effect on the reproduction of HSV-1. The use of Pluronic F-127 as a nanoscale delivery vehicle did not increase the antiherpetic activity of the porphyrins used. However, its use may have a positive effect on the photodynamic activity of porphyrins in future studies. The obtained compounds are promising for the development of utilitarian antiviral agents and, possibly, medical antiviral drugs.

Supplementary Materials: The following are available at https://www.mdpi.com/1424-8247/14/3 /242/s1, spectral data of synthesized compounds and data for virucidal activity is available.

Author Contributions: Manuscript conception, K.A.Z.; writing and original draft preparation, N.A.B., O.N.S. and K.A.Z.; synthesis of derivatives I.O.S., K.A.Z. and A.V.E.; NMR analysis, A.P.Z. and K.Y.Z.; mass-spectrometry analysis A.P.Z.; editing, data analysis and interpretation, K.A.Z., A.F.M. and O.N.S.; biological study and interpretation O.N.S., A.A.B., I.S.F., N.I.F. and N.N.S. All authors have read and agreed to the published version of the manuscript.

Funding: The reported study was funded by the Russian Science Foundation, project number 20-73-00286.

Institutional Review Board Statement: Not applicable.

Informed Consent Statement: Not applicable.

Data Availability Statement: The data presented in this study are available within the article, the associated Supplementary Materials, or on request from the corresponding author.

Conflicts of Interest: The authors declare no conflict of interest. 


\section{References}

1. Chayavichitsilp, P.; Buckwalter, J.V.; Krakowski, A.C.; Friedlander, S.F. Herpes Simplex. Pediatr. Rev. 2009, 30, 119-130. [CrossRef]

2. Cardone, G.; Heymann, J.B.; Cheng, N.; Trus, B.L.; Steven, A.C. Procapsid Assembly, Maturation, Nuclear Exit: Dynamic Steps in the Production of Infectious Herpesvirions. Adv. Exp. Med. Biol. 2011, 726, 423-439. [CrossRef]

3. Imbronito, A.V.; Grande, S.R.; Freitas, N.M.; Okuda, O.; Lotufo, R.F.; Nunes, F.D. Detection of Epstein-Barr virus and human cytomegalovirus in blood and oral samples: Comparison of three sampling methods. J. Oral. Sci. 2008, 50, 25-31. [CrossRef]

4. Looker, K.J.; Magaret, A.S.; May, M.T.; Turner, K.M.E.; Vickerman, P.; Gottlieb, S.L.; Newman, L.M. Global and Regional Estimates of Prevalent and Incident Herpes Simplex Virus Type 1 Infections in 2012. PLoS ONE 2015, 10, e0140765. [CrossRef] [PubMed]

5. Looker, K.J.; Magaret, A.S.; May, M.T.; Turner, K.M.; Vickerman, P.; Newman, L.M.; Gottlieb, S.L. First estimates of the global and regional incidence of neonatal herpes infection. Lancet Glob. Health 2017, 5, e300-e309. [CrossRef]

6. Nicoll, M.P.; Proença, J.T.; Efstathiou, S. The molecular basis of herpes simplex virus latency. FEMS Microbiol. Rev. 2012, 36, 684-705. [CrossRef]

7. Mangold, C.A.; Szpara, M.L. Persistent Infection with Herpes Simplex Virus 1 and Alzheimer's Disease-A Call to Study How Variability in Both Virus and Host may Impact Disease. Viruses 2019, 11, 966. [CrossRef]

8. Khoury-Hanold, W.; Yordy, B.; Kong, P.; Kong, Y.; Ge, W.; Szigeti-Buck, K.; Ralevski, A.; Horvath, T.L.; Iwasaki, A. Viral Spread to Enteric Neurons Links Genital HSV-1 Infection to Toxic Megacolon and Lethality. Cell Host Microbe 2016, 19, 788-799. [CrossRef] [PubMed]

9. Bibert, S.; Piret, J.; Quinodoz, M.; Collinet, E.; Zoete, V.; Michielin, O.; Menasria, R.; Meylan, P.; Bihl, T.; Erard, V.; et al. Herpes simplex encephalitis in adult patients with MASP-2 deficiency. PLOS Pathog. 2019, 15, e1008168. [CrossRef]

10. Grünewald, K.; Desai, P.; Winkler, D.C.; Heymann, J.B.; Belnap, D.M.; Baumeister, W.; Steven, A.C. Three-Dimensional Structure of Herpes Simplex Virus from Cryo-Electron Tomography. Science 2003, 302, 1396-1398. [CrossRef]

11. Baumeister, J.; Fischer, R.; Eckenberg, P.; Henninger, K.; Ruebsamen-Waigmann, H.; Kleymann, G. Superior Efficacy of HelicasePrimase Inhibitor BAY 57-1293 for Herpes Infection and Latency in the Guinea Pig Model of Human Genital Herpes Disease. Antivir. Chem. Chemother. 2007, 18, 35-48. [CrossRef] [PubMed]

12. De Clercq, E.; Field, H.J. Antiviral prodrugs-The development of successful prodrug strategies for antiviral chemotherapy. Br. J. Pharmacol. 2006, 147, 1-11. [CrossRef] [PubMed]

13. Elion, G.B.; Furman, P.A.; Fyfe, J.A.; De Miranda, P.; Beauchamp, L.; Schaeffer, H.J. Selectivity of action of an antiherpetic agent, 9-(2-hydroxyethoxymethyl)guanine. Proc. Natl. Acad. Sci. USA 1977, 74, 5716-5720. [CrossRef] [PubMed]

14. Sanchez, R.M.; Erhard, K.; Hardwicke, M.A.; Lin, H.; McSurdy-Freed, J.; Plant, R.; Raha, K.; Rominger, C.M.; Schaber, M.D.; Spengler, M.D.; et al. Synthesis and structure-activity relationships of 1,2,4-triazolo [1,5-a]pyrimidin-7(3H)-ones as novel series of potent $\beta$ isoform selective phosphatidylinositol 3-kinase inhibitors. Bioorganic Med. Chem. Lett. 2012, 22, 3198-3202. [CrossRef]

15. Sergerie, Y.; Boivin, G. Hydroxyurea enhances the activity of acyclovir and cidofovir against herpes simplex virus type 1 resistant strains harboring mutations in the thymidine kinase and/or the DNA polymerase genes. Antivir. Res. 2008, 77, 77-80. [CrossRef]

16. Urbani, M.; Grätzel, M.; Nazeeruddin, M.K.; Torres, T. Meso-Substituted Porphyrins for Dye-Sensitized Solar Cells. Chem. Rev. 2014, 114, 12330-12396. [CrossRef]

17. Li, L.-L.; Diau, E.W.-G. Porphyrin-sensitized solar cells. Chem. Soc. Rev. 2013, 42, 291-304. [CrossRef]

18. Ezhov, A.V.; Vyalba, F.Y.; Zhdanova, K.A.; Mironov, A.F.; Zhizhin, K.Y.; Bragina, N.A. Synthesis and properties comparison of meso-arylporphyrins metal complexes as potential dyes for solar cells. Fine Chem. Technol. 2018, 13, 21-30. [CrossRef]

19. Ezhov, A.V.; Zhdanova, K.A.; Bragina, N.A.; Mironov, A.F. Approaches to Improve Efficiency of Dye-Sensitized Solar Cells. Macroheterocycles 2016, 9, 337-352. [CrossRef]

20. Paolesse, R.; Nardis, S.; Monti, D.; Stefanelli, M.; Di Natale, C. Porphyrinoids for Chemical Sensor Applications. Chem. Rev. 2017, 117, 2517-2583. [CrossRef]

21. Castillero, P.; Roales, J.; Lopes-Costa, T.; Sánchez-Valencia, J.R.; Barranco, A.; González-Elipe, A.R.; Pedrosa, J.M. Optical Gas Sensing of Ammonia and Amines Based on Protonated Porphyrin/TiO2 Composite Thin Films. Sensors 2016, 17, 24. [CrossRef] [PubMed]

22. Chen, Y.; Li, A.; Huang, Z.-H.; Wang, L.-N.; Kang, F. Porphyrin-Based Nanostructures for Photocatalytic Applications. Nanomaterials 2016, 6, 51. [CrossRef]

23. Li, J.; Ren, Q.; Liu, L.; Sun, K.; Gu, X. Non-covalent conjugation of sulfonated porphyrins to polyethylenimine-grafted multiwalled carbon nanotubes as efficient recyclable heterogeneous catalysts for dihydroxynaphthalenes photooxidation. Mol. Catal. 2019, 470, 97-103. [CrossRef]

24. Ezhov, A.V.; Vyal'Ba, F.Y.; Zhdanova, K.A.; Zhdanov, A.P.; Zhizhin, K.Y.; Kluykin, I.N.; Bragina, N.A.; Mironov, A.F. Synthesis of donor- $\pi$-acceptor porphyrins for DSSC: DFT-study, comparison of anchoring mode and effectiveness. J. Porphyr. Phthalocyanines 2020, 24, 538-547. [CrossRef]

25. Kwiatkowski, S.; Knap, B.; Przystupski, D.; Saczko, J.; Kędzierska, E.; Knap-Czop, K.; Kotlińska, J.; Michel, O.; Kotowski, K.; Kulbacka, J. Photodynamic therapy-Mechanisms, photosensitizers and combinations. Biomed. Pharmacother. 2018, 106, 1098-1107. [CrossRef]

26. Buczek, K.; Trytek, M.; Deryło, K.; Borsuk, G.; Rybicka-Jasińska, K.; Gryko, D.; Cytryńska, M.; Tchórzewski, M. Bioactivity studies of porphyrinoids against microsporidia isolated from honeybees. Sci. Rep. 2020, 10, 11553. [CrossRef] [PubMed] 
27. Mironov, A.F.; Zhdanova, K.; Bragina, N. Nanosized vehicles for delivery of photosensitizers in photodynamic diagnosis and therapy of cancer. Russ. Chem. Rev. 2018, 87, 859-881. [CrossRef]

28. Civantos, F.J.; Karakullukcu, B.; Biel, M.; Silver, C.E.; Rinaldo, A.; Saba, N.F.; Takes, R.P.; Poorten, V.V.; Ferlito, A. A Review of Photodynamic Therapy for Neoplasms of the Head and Neck. Adv. Ther. 2018, 35, 324-340. [CrossRef] [PubMed]

29. Basso, G.; Cargnelutti, J.F.; Oliveira, A.L.; Acunha, T.V.; Weiblen, R.; Flores, E.F.; Iglesias, B.A. Photodynamic inactivation of selected bovine viruses by isomeric cationic tetra-platinated porphyrins. J. Porphyr. Phthalocyanines 2019, 23, 1041-1046. [CrossRef]

30. Costa, L.; Faustino, M.A.F.; Neves, M.G.P.M.S.; Cunha, Â.; Almeida, A. Photodynamic Inactivation of Mammalian Viruses and Bacteriophages. Viruses 2012, 4, 1034-1074. [CrossRef]

31. Tomé, J.P.; Silva, E.M.; Pereira, A.M.; Alonso, C.M.; Faustino, M.A.; Neves, M.G.; Tomé, A.C.; Cavaleiro, J.A.; Tavares, S.A.; Duarte, R.R.; et al. Synthesis of neutral and cationic tripyridylporphyrin-d-galactose conjugates and the photoinactivation of HSV-1. Bioorganic Med. Chem. 2007, 15, 4705-4713. [CrossRef] [PubMed]

32. Silva, E.M.; Giuntini, F.; Faustino, M.A.; Tomé, J.P.; Neves, M.G.; Tomé, A.C.; Silva, A.M.; Santana-Marques, M.G.; Ferrer-Correia, A.J.; Cavaleiro, J.A.; et al. Synthesis of cationic $\beta$-vinyl substituted meso-tetraphenylporphyrins and their in vitro activity against herpes simplex virus type. Bioorganic Med. Chem. Lett. 2005, 15, 3333-3337. [CrossRef] [PubMed]

33. Sengupta, D.; Timilsina, U.; Mazumder, Z.H.; Mukherjee, A.; Ghimire, D.; Markandey, M.; Upadhyaya, K.; Sharma, D.; Mishra, N.; Jha, T.; et al. Dual activity of amphiphilic Zn(II) nitroporphyrin derivatives as HIV-1 entry inhibitors and in cancer photodynamic therapy. Eur. J. Med. Chem. 2019, 174, 66-75. [CrossRef]

34. Neris, R.L.S.; Figueiredo, C.M.; Higa, L.M.; Araujo, D.F.; Carvalho, C.A.M.; Verçoza, B.R.F.; Silva, M.O.L.; Carneiro, F.A.; Tanuri, A.; Gomes, A.M.O.; et al. Co-protoporphyrin IX and Sn-protoporphyrin IX inactivate Zika, Chikungunya and other arboviruses by targeting the viral envelope. Sci. Rep. 2018, 8, 9805. [CrossRef]

35. Moura, N.M.; Esteves, M.; Vieira, C.; Rocha, G.M.; Faustino, M.A.F.; Almeida, A.; Cavaleiro, J.A.; Lodeiro, C.; Neves, M.G.P. Novel $\beta$-functionalized mono-charged porphyrinic derivatives: Synthesis and photoinactivation of Escherichia coli. Dyes Pigment. 2019, 160, 361-371. [CrossRef]

36. Tsolekile, N.; Nelana, S.; Oluwafemi, O.S. Porphyrin as Diagnostic and Therapeutic Agent. Molecules 2019, 24, 2669. [CrossRef]

37. Wang, J.; Yang, X.; Song, H.; Liao, W.; Zhuo, L.; Wang, G.; Wei, H.; Yang, Y.; Luo, S.; Zhou, Z. Visible light-induced biocidal activities and mechanistic study of neutral porphyrin derivatives against S. aureus and E. coli. J. Photochem. Photobiol. Biol. 2018, 185, 199-205. [CrossRef]

38. Sampedro, A.G.; Tabero, A.; Mahamed, I.; Acedo, P. Multimodal use of the porphyrin TMPyP: From cancer therapy to antimicrobial applications. J. Porphyr. Phthalocyanines 2019, 23, 11-27. [CrossRef]

39. Moghnie, S.; Tovmasyan, A.; Craik, J.; Batinic-Haberle, I.; Benov, L. Cationic amphiphilic Zn-porphyrin with high antifungal photodynamic potency. Photochem. Photobiol. Sci. 2017, 16, 1709-1716. [CrossRef] [PubMed]

40. Cormick, M.P.; Alvarez, M.G.; Rovera, M.; Durantini, E.N. Photodynamic inactivation of Candida albicans sensitized by tri- and tetra-cationic porphyrin derivatives. Eur. J. Med. Chem. 2009, 44, 1592-1599. [CrossRef] [PubMed]

41. Musetti, C.; Spagnul, C.; Mion, G.; Da Ros, S.; Gianferrara, T.; Sissi, C. DNA Targeting by Cationic Porphyrin-Ruthenium(II) Conjugates. ChemPlusChem 2014, 80, 158-168. [CrossRef]

42. Artusi, S.; Nadai, M.; Perrone, R.; Biasolo, M.A.; Palù, G.; Flamand, L.; Calistri, A.; Richter, S.N. The Herpes Simplex Virus-1 genome contains multiple clusters of repeated G-quadruplex: Implications for the antiviral activity of a G-quadruplex ligand. Antivir. Res. 2015, 118, 123-131. [CrossRef]

43. Sun, R.W.-Y.; Yu, W.-Y.; Sun, H.; Che, C.-M. In Vitro Inhibition of Human Immunodeficiency Virus Type-1 (HIV-1) Reverse Transcriptase by Gold(III) Porphyrins. ChemBioChem 2004, 5, 1293-1298. [CrossRef]

44. Majiya, H.; Adeyemi, O.O.; Stonehouse, N.J.; Millner, P. Photodynamic inactivation of bacteriophage MS2: The A-protein is the target of virus inactivation. J. Photochem. Photobiol. Biol. 2018, 178, 404-411. [CrossRef] [PubMed]

45. Zupán, K.; Egyeki, M.; Tóth, K.; Fekete, A.; Herényi, L.; Módos, K.; Csik, G. Comparison of the efficiency and the specificity of DNA-bound and free cationic porphyrin in photodynamic virus inactivation. J. Photochem. Photobiol. Biol. 2008, 90, 105-112. [CrossRef] [PubMed]

46. Casteel, M.J.; Jayaraj, K.; Gold, A.; Ball, L.M.; Sobsey, M.D. Photoinactivation of Hepatitis A Virus by Synthetic Porphyrins. Photochem. Photobiol. 2004, 80, 294. [CrossRef]

47. Tabish, T.A.; Hamblin, M.R. Multivalent nanomedicines to treat COVID-19: A slow train coming. Nano Today 2020, 35, 100962. [CrossRef] [PubMed]

48. Alekseeva, A.; Kapkaeva, M.; Shcheglovitova, O.; Boldyrev, I.; Pazynina, G.; Bovin, N.; Vodovozova, E. Interactions of antitumour Sialyl Lewis X liposomes with vascular endothelial cells. Biochim. Biophys. Acta Biomembr. 2015, 1848, 1099-1110. [CrossRef]

49. Lamch, Ł.; Pucek, A.; Kulbacka, J.; Chudy, M.; Jastrzębska, E.; Tokarska, K.; Bułka, M.; Brzózka, Z.; Wilk, K.A. Recent progress in the engineering of multifunctional colloidal nanoparticles for enhanced photodynamic therapy and bioimaging. Adv. Colloid Interface Sci. 2018, 261, 62-81. [CrossRef]

50. Solov'Eva, A.B.; Savko, M.A.; Glagolev, N.N.; Aksenova, N.A.; Timashev, P.S.; Bragina, N.A.; Zhdanova, K.A.; Mironov, A.F. Photogeneration of Singlet Oxygen by Tetra(p-Hydroxyphenyl)porphyrins Modified with Oligo- and Polyalkylene Oxides. Russ. J. Phys. Chem. 2018, 92, 1621-1626. [CrossRef] 
51. Zhdanova, K.; Savelyeva, I.; Ignatova, A.; Gradova, M.; Gradov, O.; Lobanov, A.; Feofanov, A.; Mironov, A.; Bragina, N. Synthesis and photodynamic antimicrobial activity of amphiphilic meso-arylporphyrins with pyridyl moieties. Dyes Pigment. 2020, 181, 108561. [CrossRef]

52. Lindsey, J.S.; Hsu, H.C.; Schreiman, I.C. Synthesis of tetraphenylporphyrins under very mild conditions. Tetrahedron Lett. 1986, 27, 4969-4970. [CrossRef]

53. Fedulova, I.N.; Bragina, N.A.; Novikov, N.V.; Mironov, A.F.; Bykova, V.V.; Usol'Tseva, N.V.; Ananieva, G.A. Synthesis and mesomorphism of tetraphenylporphyrin derivatives. Mendeleev Commun. 2008, 18, 324-326. [CrossRef]

54. Ormond, A.B.; Freeman, H.S. Effects of substituents on the photophysical properties of symmetrical porphyrins. Dyes Pigment. 2013, 96, 440-448. [CrossRef]

55. Kano, K.; Fukuda, K.; Wakami, H.; Nishiyabu, R.; Pasternack, R.F. Factors Influencing Self-Aggregation Tendencies of Cationic Porphyrins in Aqueous Solution. J. Am. Chem. Soc. 2000, 122, 7494-7502. [CrossRef]

56. Tozoni, J.R.; Neto, N.B.; Ribeiro, C.; Pazin, W.; Ito, A.; Borissevitch, I.; Marletta, A. Relationship between porphyrin aggregation and formation of porphyrin ring structures in poly(n-alkyl methacrylate)/porphyrin blends. Polymers 2016, 102, 136-142. [CrossRef]

57. Sigge, U.; Bindig, C.; Endisch, T.; Komatsu, E.; Tsuchida, J.; Voigt, J.H. Fuhrhop. Photophysical and photochemical prop-erties of porphyrin aggregates. Ber. Bunsenges. Phys. Chem. 1996, 100, 2070-2075. [CrossRef]

58. Gradova, M.A.; Gradov, O.; Zhdanova, K.A.; Bragina, N.A.; Lobanov, A.V. Self-assembly of amphiphilic meso-aryl-substituted porphyrin derivatives in the presence of surfactants. J. Porphyr. Phthalocyanines 2020, 24, 505-514. [CrossRef]

59. Whitesides, G.M.; Mathias, J.P.; Seto, C.T. Molecular self-assembly and nanochemistry: A chemical strategy for the synthesis of nanostructures. Science 1991, 254, 1312-1319. [CrossRef] [PubMed]

60. Managa, M.; Ngoy, B.P.; Mafukidze, D.; Nyokong, T. Incorporation of metal free and Ga 5,10,15,20-tetrakis(4-bromophenyl) porphyrin into Pluronic F127-folic acid micelles. J. Lumin 2018, 194, 739-746. [CrossRef]

61. Managa, M.; Achadu, O.J.; Nyokong, T. Photophysical studies of graphene quantum dots-Pyrene-derivatized porphyrins conjugates when encapsulated within Pluronic F127 micelles. Dyes Pigment. 2018, 148, 405-416. [CrossRef]

62. Vilsinski, B.H.; Aparicio, J.L.; Pereira, P.C.D.S.; Fávaro, S.L.; Campanholi, K.S.S.; Gerola, A.P.; Tessaro, A.L.; Hioka, N.; Caetano, W. Physico-chemical properties of meso-tetrakis(p-methoxyphenyl)porphyrin (tmpp) incorporated into pluronic tm p-123 and f-127 polymeric micelles. Quimica Nova 2014, 37, 1650-1656. [CrossRef]

63. Kadish, K.M.; Smith, K.M.; Guilard, R. The Porphyrin Handbook; Synthesis and Organic Chemistry; Academic Press: New York, NY, USA, 2000; Volume 1. 